\title{
Resilience Approach of Ayurveda: nCOV-19 Pandemic
}

\author{
Research Article
}

\section{Vijay Mohan Soni', Shiv Singh², Neha Munjal ${ }^{*}$}

\section{Medical Officer, Uni-Hospital, Lovely Faculty of Applied Medical Sciences (LFAMS), Lovely Professional University, G. T. Rd, Phagwara, Punjab. \\ 2. Assistant Librarian, Department of Library, \\ Bennett University (Times of India Group), Tech Zone II, Greater Noida, Uttar Pradesh.}

3. Assistant Professor, Department of Physics, School of Chemical Engineering and Physical Sciences, Lovely Professional University, G. T. Rd, Phagwara, Punjab.

\begin{abstract}
Introduction: The coronavirus disease, $\mathrm{nCOV}-19$ pandemic is exceptional and unprecedented in many aspects and it has shaken the health care system at global level. The several studies reported on nCOV-19 suggest that, immunization is the only way to fight against it. For this, Ayurveda is the most imperative as it recommends a healthy lifestyle instead of the mere prescription of medicines. Methodology: Ministry of Ayurveda, Yoga \& Naturopathy, Unani, Siddha and Homoeopathy is purposed with developing education, research and propagation of indigenous alternative medicine systems in India (Ministry of AYUSH). The Ministry is headed by a Minister of State, which is currently held by Shripad Yesso Naik and has recommended some measures to be followed in building strength by following the holistic approach of Ayurveda toward Swasthavritta. Thus, the present paper focuses on analysing the public perception towards Ayurveda measures using the most popular statistical techniques as ANOVA. Results: The analysis of data indicated that, the people are mesmerised by the concept of Ayurveda and are following all the possible precautions to save themselves from the effect of COVID-19. Older generation has a firm believe on the vedic science as compared to the younger generation. Conclusion: The classic of Ayurveda 'Charaka Samhita' describes the epidemic management and it defines immunity as the most essential to prevent diseases and arrest its progress. The foundation of Ayurveda is to building strength of mind and body to manage with different stressors, including infections. The Ayurveda concept of immunity (Bala or strength) is categorized as natural (Sahaja), chronobiologic (Kalaja), and acquired (Yuktikrut). Henceforth, we can achieve the aim of Ayurveda i.e. the Swasthasya Swasthya Rakshanam and Aturasya Vikar Prashamanam, against nCOV-19 pandemic.
\end{abstract}

Key Words: Covid-19, Ayurveda, Ministry of AYUSH, ANOVA, Pandemic, Atharva veda.

\section{Introduction}

Ayurveda, a branch of Vedic Science, literally means "the science of life" and originated in India as the traditional healing system over 5,000 years ago. The term Ayurveda is derived from the Sanskrit word ayur, meaning "life" or "longevity," and veda, meaning "knowledge" or "science."According to Charak Sutra (1-2). "what is good (hita) and what is bad (ahita) for the four different types of ayus (namely, hitayu, ahitayu, sukhayu and dukhayu, concerning different conditions of diseased or healthy life) is Ayurveda ". Ayurveda explores life and all its layers. The concept of Ayurveda has been divided in two aspects Swasthasya Swasthya Rakshanam (Preventive and Social medicine) and Aturasya Vikar Prashamanam (Therapeutics). The purpose of Ayurveda is to help the healthy person to

\section{* Corresponding Author:}

\section{Neha Munjal}

Assistant Professor, Department of Physics, School of Chemical Engineering and Physical Sciences,

Lovely Professional University, G. T. Rd. Phagwara,

Punjab-144411, India.

Email Id: neha.18869@1pu.co.in maintain good health and diseased person to regain good health. The practice of Ayurveda is designed to promote human happiness at physical, mental and spiritual level. By the proper balance of all vital energies in the body, the processes of physical deterioration and disease can be reduced. This can be accomplished through proper eating, thinking and living habits as well as the use of herbal remedies to treat illness. Ayurveda provides us with a multitude of daily practices, food guidelines, herbal remedies and body therapies to help create a harmonious external and internal world. That will facilitate healing not only physically and mentally (deep within our beings) (3-4).

In, Charaka Samhita (1) there is a chapter called "Janapada Dvamsa Vyadhi", which means epidemics and presently world is facing the nCOV-19.

The Ayurveda has been proved to promising in treating several disorders and diseases (5-26). The ancient history of Ayurveda explains that following the dinacharya and pranayama for healthy living. Thus, Ministry of AYUSH, India has given the proper guidelines to follow the healthy routine as mentioned in ancient science to improve immune system and to fight with nCOV-19 (27). 
In the present work, the data is collected through random sampling to understand the perspectives of the Indian public towards Ayurveda and their beliefs.

\section{Methodology}

The random sampling technique has been used to take opinion of public regarding the guidelines issued by Ministry of AYUSH to be followed for enhancing the immunity. The questionnaire method has been adopted to take the responses. The Google form was created and circulated through the social media sites such as Whatsapp, Facebook, E-mail etc. The link was shared using the snowball sampling techniques, for obtaining the responses from the wider area. In total, 2872 responses were recorded, out of which 2519 were properly filled and they were analyzed using descriptive and inferential statistic techniques. These 2519, response were segregated on the basis of age and gender for analysis. The analysis has been done using ANOVA. It is Analysis of variance which comprises of the collection of statistical models and their associated estimation procedures such as the variation among and between groups. It is used for testing the hypothesis, where the variation of the data is to studied among the groups using the value of mean.

To check the variability, the F statistic is considered, it is a measure of the variability between treatments divided by a measure of the variability within treatments. If $\mathrm{F}$ is large, the variability between treatments is large relative to the variation within treatments, and we reject the null hypothesis of equal means. If $F$ is small, the variability between treatments is small relative to the variation within treatments, and we do not reject the null hypothesis of equal means. The ANOVA table is represented as

\begin{tabular}{l|llll} 
Source & SS & df & MS & F \\
\hline Model/Group & SSG & $k-1$ & MSG $=\frac{S S G}{k-1}$ & $\frac{M S G}{M S E}$ \\
Residual/Error & SSE & $n-k$ & MSE $=\frac{S S E}{n-k}$ & \\
\hline Total & SST & $n-1$ & &
\end{tabular}

Here,

$\mathrm{SS}=$ Sum of Squares (sum of squared deviations)

SST measures variation of the data around the overall mean

SSG measures variation of the group means around the overall mean

SSE measures the variation of each observation around its group mean

\section{Degree of freedom}

$\mathrm{k}-1$ for $\mathrm{SSG}$, since it measures the variation of the $\mathrm{k}$ group means about the overall mean

$\mathrm{n}-\mathrm{k}$ for SSE, since it measures the variation of the $\mathrm{n}$ observations about $\mathrm{k}$ group means

$\mathrm{n}-1$ for SST, since it measures the variation of all $\mathrm{n}$ observations about the overall mean

MS $=$ Mean Square $=$ SS $/ \mathrm{df}$

The $\mathrm{F}$ statistic $=$ MSG $/$ MSE
If the null hypothesis is true, the F statistic has an $\mathrm{F}$ distribution with $\mathrm{k}-1$ and $\mathrm{n}-\mathrm{k}$. If the alternate hypothesis is true, then $\mathrm{F}$ tends to be large and null hypothesis Ho is rejected. F statistics and can also be compared using the $\mathrm{P}$ value method.

\section{Hypothesis}

The Null hypothesis framed were

1. The general Ayurveda measures as prescribed by Ministry of Ayush are followed by everyone irrespective of age groups

2. The Ayurveda immunity promoting measures as prescribed by Ministry of Ayush are followed by everyone irrespective of age groups

3. The simple Ayurveda procedures as prescribed by Ministry of Ayush are followed by everyone irrespective of age groups

4. During dry cough/sore throat precautions as prescribed by Ministry of Ayush are followed by everyone irrespective of age groups

The above hypothesis were tested using Anova technique.

\section{Data Interpretation}

The complete data set is presented in Table 1, it consists of 1268 Males, 1250 Females and which is further categorized into age groups. The respondents were from 26 states of India.

\begin{tabular}{|l|c|c|c|}
\hline \multicolumn{4}{|c|}{ Table 1: Data set } \\
\\
\hline \multicolumn{1}{|c|}{ Age } & Male & Female & Total \\
\hline $18-28$ & 300 & 291 & 591 \\
\hline $29-39$ & 279 & 286 & 565 \\
\hline $40-50$ & 290 & 265 & 555 \\
\hline $51-59$ & 230 & 218 & 448 \\
\hline 60 and above & 170 & 190 & 360 \\
\hline Total & 1269 & 1250 & 2519 \\
\hline
\end{tabular}

Further, the first question was "Do you believe in Ayurveda remedies for fighting the war against nCOV-19". Figure 1 demonstrates the responses as per the age and gender. It clearly depicts that the younger generation believes less in Ayurveda as compared to older generation.

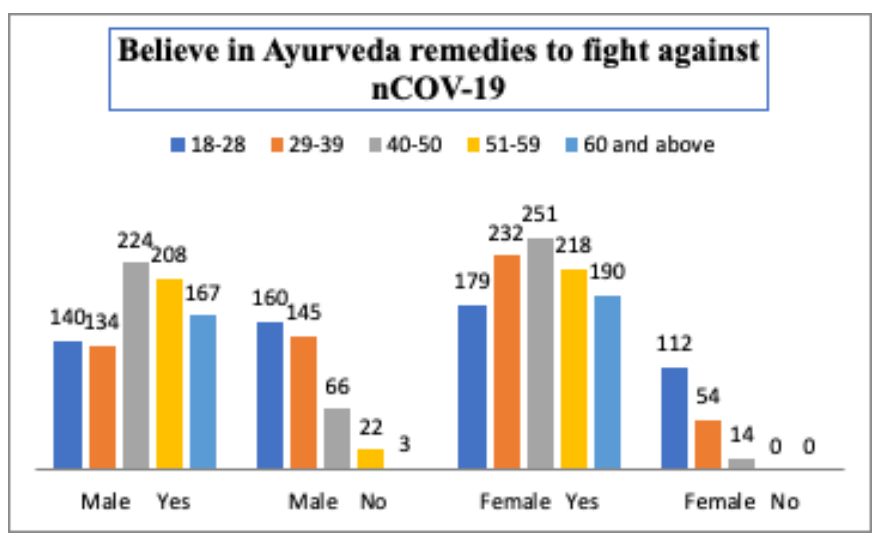

Figure 1. Belief in Ayurveda remedies to fight against nCOV-19. 
The second block of the questionnaire was about the practicing of general measures of Ayurveda as per the guidelines of Ministry of Ayush. It consists of three parameters

I. Drinking of warm water throughout the Day

II. Daily practice of Yogasana, Pranayama and meditation for at least 30 minutes as advised by Ministry of AYUSH

III. Spices like Haldi (Turmeric), Jeera (Cumin), Dhaniya (Coriander) and Lahsun (Garlic) are recommended in cooking.

Figure 2 represents the perception of above parameters as per segregation of demographic variables. For all age groups, females have more belief on Ayurveda in comparison to males. The result ANOVA indicates (Table 2) that respondents have different opinion as per the age group, thus rejecting the Hypothesis 1.

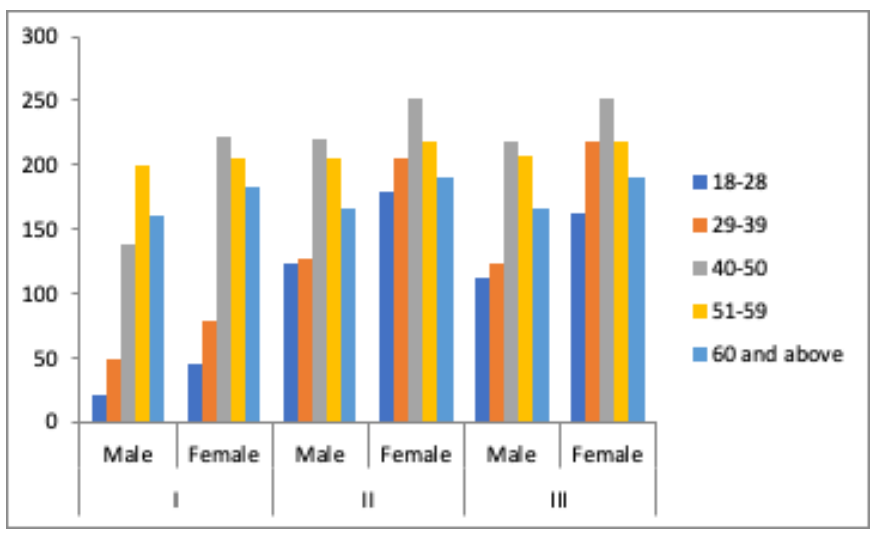

Figure 2. Perspectives about the General Measures as per the Ministry of Ayush

Table 2: Analysis for general measures

\begin{tabular}{|l|c|c|c|c|c|c|}
\hline Source of Variation & $\begin{array}{c}\text { Sum of } \\
\text { squares (SS) }\end{array}$ & $\begin{array}{c}\text { Degree of } \\
\text { freedom (df) }\end{array}$ & $\begin{array}{c}\text { Mean square } \\
\text { (MS) }\end{array}$ & F statistics & P-value & $\begin{array}{c}\text { F critical } \\
\text { value }\end{array}$ \\
\hline Between Groups & 67427.73 & 4 & 16856.9 & 11.765 & 0.00085 & 3.47805 \\
\hline Within Groups & 14328 & 10 & 1432.8 & & & \\
\hline Total & 81755.73 & 14 & & & &
\end{tabular}

The third block of the questionnaire was about Ayurvedic Immunity Promoting Measures. Which was further categorized by the three subsets as follows

I. Take Chyavanprash $10 \mathrm{gm}$ (1tsf) in the morning.

II. Drink herbal tea / decoction (Kadha) made from Tulsi (Basil), Dalchini (Cinnamon), Kalimirch (Black pepper), Shunthi (Dry Ginger) and Munakka (Raisin) - once or twice a day.

III. Golden Milk- Half tea spoon Haldi (turmeric) powder in $150 \mathrm{ml}$ hot milk - once or twice a day.

Figure 3 represents the perception of above parameters as per segregation of demographic variables. For age group 18-28 and 29-39 refer the first measure taking Chyavanprash is least preferred. The respondents in the age group of 18-28 prefer to drink herbal tea/ kadha to boost immunity, whereas 29-39 age group respondents have more preference to Golden Milk. The older generation is following all the measures to protect themselves from nCOV-19. For all age groups, the females are more inclined towards Ayurveda measures. The result ANOVA indicates (Table 3) that respondents have different opinion as per the age group, thus rejecting the Hypothesis 2.

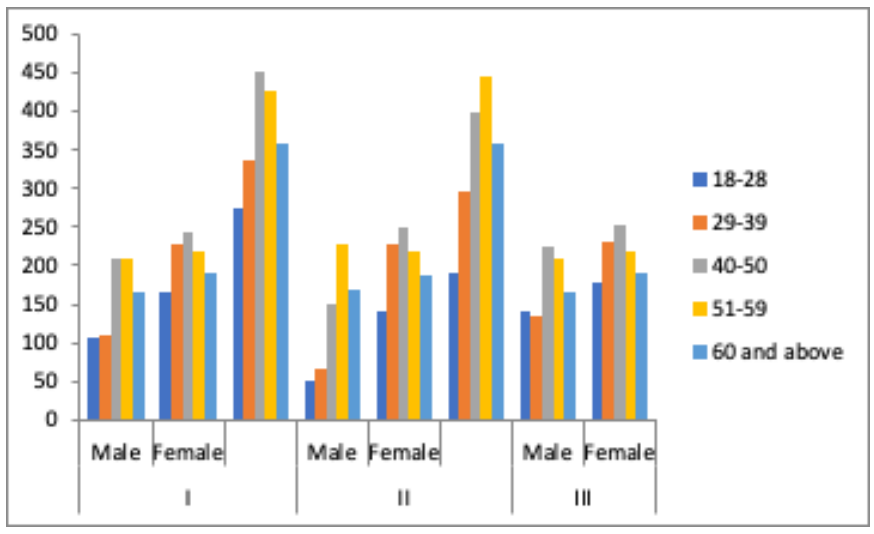

Figure 3. Perspectives about the Ayurvedic Immunity Promoting Measures as per the Ministry of Ayush

\begin{tabular}{|l|c|c|c|c|c|c|}
\hline \multicolumn{7}{|c|}{ Table 3: Analysis for Immunity Promoting Measures } \\
\hline \multicolumn{1}{|c|}{ Source of Variation } & SS & df & MS & F & P-value & F crit \\
\hline Between Groups & 108404.9 & 4 & 27101.23 & 3.829805 & 0.038685 & 3.47805 \\
\hline Within Groups & 70764 & 10 & 7076.4 & & & \\
\hline Total & 179168.9 & 14 & & & & \\
\hline
\end{tabular}

The fourth block of the questionnaire was about Simple Ayurveda Procedures. Which was further categorized into the two subsets as follows

I. Nasal application

II. Oil Pulling Therapy

Figure 4 represents the perception of above parameters. The Nasal application is preferred more as compared to Oil pulling therapy. For age group above

60, 162 males and 190 females are using Nasal therapy, whereas 110 males and 123 females are Oil pulling therapy. For this section also the most dominating are females towards Ayurveda procedures. The result ANOVA indicates (Table 4) that respondents have same opinion as per the age group, thus accepting the Hypothesis 3. 


\begin{tabular}{|l|c|c|c|c|c|c|}
\hline & Table 4: Analysis of Ayurveda Procedures & & \\
\hline \multicolumn{1}{|c|}{ Source of Variation } & SS & df & MS & F & P-value & F crit \\
\hline Between Groups & 39593.4 & 4 & 9898.35 & 0.724989 & 0.611149 & 5.192168 \\
\hline Within Groups & 68265.5 & 5 & 13653.1 & & & \\
\hline Total & 107858.9 & 9 & & & & \\
\hline
\end{tabular}

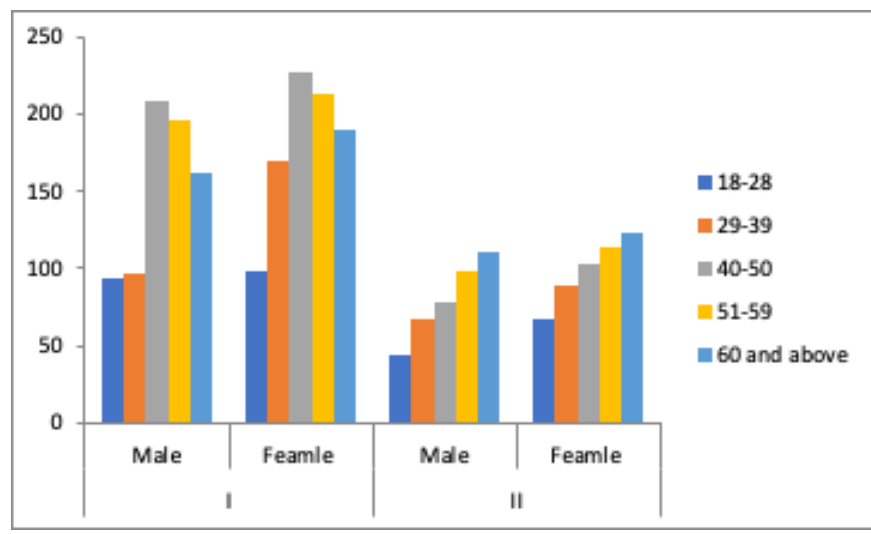

Figure 4. Perspectives about the Ayurveda Procedures as per the Ministry of Ayush

The fifth block of the questionnaire was about procedures followed during dry cough/sore throat. Which was further categorized into the two subsets as follows

I. Steam inhalation with fresh Pudina (Mint) leaves or Ajwain (Caraway seeds) can be practiced once in a day.

II. Lavang (Clove) powder mixed with natural sugar / honey can be taken 2-3 times a day in case of cough or throat irritation.
Figure 5 represents the perception of above parameters. The above both remedies are followed but the inclination is slightly more towards the steam inhalation. The older generation is trying to follow the both procedures to prevent themselves from severe infection. The result of ANOVA indicates (Table 5) that respondents have same opinion as per the age group, thus accepting the Hypothesis 4.

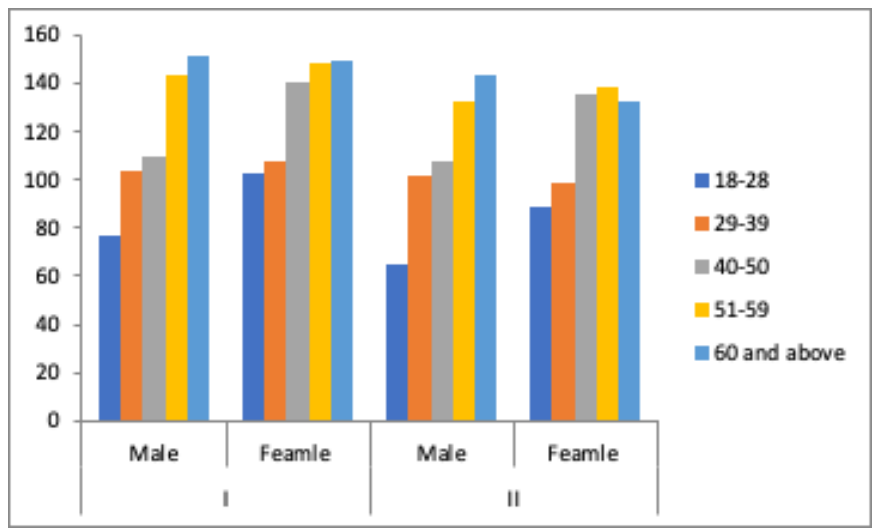

Figure 5. Perspectives about the Ayurveda Procedures as per the Ministry of Ayush

\begin{tabular}{|l|c|c|c|c|c|c|c|}
\hline \multicolumn{7}{c}{ Table 5: Analysis for Measures taken during Sore throat } \\
\hline Source of Variation & SS & df & MS & F & P-value & F crit \\
\hline Between Groups & 20722.4 & 4 & 5180.6 & 27.09519 & 0.001384 & 5.192168 \\
\hline Within Groups & 956 & 5 & 191.2 & & & \\
\hline Total & 21678.4 & 9 & & & & \\
\hline
\end{tabular}

\section{Conclusion}

The Ministry of AYUSH, Government of India, has issued a very useful advisory to fight the war against nCOV-19 using Indian traditional practices. The analysis of survey indicates that people have the firm believe in our ancient values Ayurveda. The younger generation is slightly less inclined towards Ayurveda beliefs. But the older generation is strictly following the measures to prevent themselves. The Ayurveda interventions have the several advantages and are promising measures for long run of human kind. The prevention is always better than cure, thus it has been suggested that to follow the daily dincharya (Healthy lifestyle) as prescribed in our Vedas. This will not only help the community to fight against the nCOV-19, it will also help in other diseases. This pandemic has warned the community and makes us recall our traditional living habits. Henceforth, we can achieve the aim of Ayurveda i.e. the Swasthasya Swasthya Rakshanam and Aturasya Vikar Prashamanam, against nCOV-19 pandemic.

\section{Acknowledgement}

Authors acknowledge the immense help received from the scholars whose articles are cited and included in references of this manuscript. The authors are also grateful to authors / editors / publishers of all those articles, journals and books from where the literature for this article has been reviewed and discussed. Authors extend the extreme gratefulness to the respondents, who devoted their valuable time in filling the questionnaire"

\section{Conflict of Interest: NIL}

\section{References}

1. Acharya Y, ed. Charaka Samhita. Varanasi, India: ChaukhambaSurbharati, 1992.

2. Bhishagratna, KK, editors-translator. Sushruta Samhita. 4th ed., 2 vols., Varanasi: Chowkhamba Sanskrit Series Office;1991. 240 p.

3. Sharma, PV, editor-translator. Caraka Samhita. 4 vols. Varanasi: Chowkhamba Sanskrit Series Office: 1981-1994.2200 p. 
4. Sharma, RK, Vaidya B D, editors translators. Caraka Samhita. 3d ed., 3 vols. Varanasi: Chowkhamba Sanskrit Series Office: 1992.

5. Singh N, Bhalla M, de Jager P, Gilca, M.An overview on Ashwagandha: a Rasayana (rejuvenator) of Ayurveda. Afr J Tradit Complement Altern Med 2011;8:208-213.

6. Sumantran VN, Tillu G. Cancer, inflammation, and insights from Ayurveda. Evid Based Complement Alternat Med 2012;2012:306346.

7. Vinjamury SP, Vinjamury M, Sucharitakul S, et al. Panchakarma: Ayurvedic detoxification and allied therapies - is there any evidence? In: EvidenceBased Practice in Complementary and Alternative Medicine. Berlin: Springer,2012:113-137

8. Watts S. Disease and medicine in world history. Disease and Medicine in World History; 2003. p. 1-166.

9. Turk C, Turk S, Malkan UY, Haznedaroglu IC. Three critical clinicobiological phases of the human SARS-associated coronavirus infections. Eur Rev Med Pharmacol Sci 2020;24(16):8606-8620.

10. Tanner CM, William Langston J. Do environmental toxins cause Parkinson's disease? A critical review. Neurology 1990;40(10):17-30.

11. Svoboda RE. Ayurveda's role in preventing disease. Indian J Med Sci 1998;52(2):70-77.

12. Singh AK, Bhushan B, Maurya A, Mishra G, Singh SK, Awasthi R. Novel coronavirus disease 2019 (COVID-19) and neurodegenerative disorders. Dermatol Ther 2020;33(4).

13. Rao RV, Descamps O, John V, Bredesen DE. Ayurvedic medicinal plants for Alzheimer's disease: A review. Alzheimers Res Ther 2012;4(3).

14. Rajurkar NS, Damame MM. Elemental analysis of some herbal plants used in the treatment of cardiovascular diseases by NAA and AAS. J RADIOANAL NUCL CHEM 1997;219(1):77-80.

15. Prashantkumar P, Vidyasagar GM. Traditional knowledge on medicinal plants used for the treatment of skin diseases in Bidar district, Karnataka. Indian J Trad Knowl 2008;7(2):273-276.

16. Nagashayana N, Sankarankutty P, Nampoothiri MRV, Mohan PK, Mohanakumar KP. Association of L-DOPA with recovery following Ayurveda medication in Parkinson's disease. J Neurol Sci 2000;176(2):124-127.
17. Mandal B. The global emergence of severe acute respiratory syndrome coronavirus 2 in human. VirusDisease 2020;31(2):67-70.

18. Man SC, Durairajan SSK, Kum WF, Lu JH, Huang JD, Cheng CF, et al. Systematic review on the efficacy and safety of herbal medicines for Alzheimer's disease. J Alzheimer's Dis 2008;14(2):209-223.

19. Konakci G, Ozgursoy Uran BN, Erkin O. In the Turkish News: Coronavirus and "Alternative \& complementary" medicine methods. Complement Ther Med 2020;53.

20. Khedekar S, Rathi RB, Rathi BJ, Deshmukh A. The rationale behind ayurveda codes of conduct (Aacharrasayana) in covid-19 like new disorders. Int J Res Pharm Sci 2020;11(Special Issue 1):391-395.

21. Jayasundar R. Ayurveda: A distinctive approach to health and disease. Curr Sci 2010;98(7):908-914.

22. Goothy SSK, Goothy S, Choudhary A, Potey GG, Chakraborty H, Kumar AHS, et al. Ayurveda's holistic lifestyle approach for the management of coronavirus disease (COVID-19): Possible role of Tulsi. Int J Res Pharm Sci 2020;11(Special Issue 1):16-18.

23. Golechha M. Time to realise the true potential of Ayurveda against COVID-19. Brain BehavImmun2020;87:130-131.

24. Chintamunnee V, Mahomoodally MF. Herbal medicine commonly used against noncommunicable diseases in the tropical island of Mauritius. J Herbal Med 2012;2(4):113-125.

25. Chakravorty RC. Head and neck diseases in an ancient Indian surgical text (The Sushruta-samhita). Med Hist 1971;15(4):393-396.

26. Auddy B, Ferreira M, Blasina F, Lafon L, Arredondo F, Dajas F, et al. Screening of antioxidant activity of three Indian medicinal plants, traditionally used for the management of ne urodegenerative diseases. J Ethnopharmacol2003;84(2-3):131-138.

27. Ministry of AYUSH, Government of India. Ayurveda's immunity boosting measures for self care during COVID19 crisis. Online document at: http://ayush.gov.in/event/ayurveda-immunityboosting-measures-self-care-duringcovid-19-crisis, accessed July 10, 2020. 